\title{
ARTYKUtY PRZEGLAZDOWE
}

W niniejszym artykule zaprezentowane zostaną korzenie nacjonalizmu baskijskiego i powody, dla których powstała organizacja terrorystyczna ETA. Na początku cieszyła się ona poparciem niemal całego narodu baskijskiego, a później zaczęła je tracić, aby w końcu zostać potępiona, jako brutalna organizacja terrorystyczna. Próba odpowiedzi na pytania: jaka jest geneza nacjonalizmu baskijskiego, w jaki sposób on ewoluowat, jakie były podstawy utworzenia ETA i jakie nastąpiły zmiany ideologiczne i taktyczne w tej organizacji oraz do czego zmierzała ETA, co osiągnęła i jak kształtuje się sytuacja obecnie, stanie się podstawą dla ukazania istoty konfliktu etnicznego w Kraju Basków.

Przedstawiony zostanie także nurt nacjonalizmu umiarkowanego realizowany przez partię PNV ${ }^{1}$ (z którym utożsamia się większość społeczeństwa baskijskiego, popierająca ideologię narodowościową).

Ujęcie historyczne wydaje się zasadne, gdyż nacjonalizm baskijski ewoluował w sposób specyficzny, a historia i zmiany polityczno-ustrojowe wpływały na niego w inny sposób niż w pozostałych regionach.

Dr Anna ANTCZAK jest analitykiem w Biurze Spraw Międzynarodowych i Unii Europejskiej Kancelarii Senatu RP oraz wykładowcą akademickim. annique@wp.pl

1 Partido Nacionalista Vasco (hiszp.) - Baskijska Partia Nacjonalistyczna. 
Baskowie bardzo podkreślają swoją narodową odrębność. Są najstarszą grupą etniczną Półwyspu Iberyjskiego i najprawdopodobniej najstarszym narodem Europy, ich przodkowie mieszkali na obecnych terenach, zanim jeszcze Rzymianie opanowali obszary dzisiejszej Francji i Hiszpanii. Baskowie są narodem pochodzenia kaukasko-azjatyckiego, a ich język (euskara), niepodobny do żadnego innego (choć ma pewne związki z walijskim, gruzińskim, szkockim, węgierskim, fińskim, a nawet japońskim i językami eskimoskimi), jak twierdzą naukowcy, pochodzi z Kaukazu i w Europie Zachodniej pojawił się w II tysiącleciu p.n.e. Baskowie, którzy nigdy nie ulegli romanizacji, nadal posługują się tym językiem.

Kraj Basków to kraina historyczna położona w północnej części Hiszpanii (wschodnie partie Gór Kantabryjskich) i południowo-zachodniej Francji, składa się z siedmiu prowincji. Po stronie hiszpańskiej są to: Guipúzcoa, Vizcaya, Alava i Navarra², pozostałe trzy - to okręgi należące do Francji: Soule, Basse Navarre i Labourd. Baskonia od I wieku p.n.e. pozostawała pod panowaniem Rzymian, ale zachowała kulturową odrębność, choć wraz z resztą imperium, Baskowie przyjęli chrześcijaństwo i jak wśród innych ludów żyjących w ubogich okolicach górskich, Kościół i księża odgrywali w Kraju Basków znaczącą rolę. Po upadku cesarstwa zachodniorzymskiego w 476 r., po którym nastąpił podbój wizygocki (połowa VI w.),

Kraj Basków szybko wyzwolit się spod ich panowania i cieszył się niezależnością aż do XI wieku, kiedy został wcielony do Królestwa Nawarry (gdy Hiszpania została podbita przez Arabów na początku VIII wieku, Baskonia pozostała w małej strefie chrześcijańskiej, natomiast próby Franków uzależnienia Kraju Basków nie powiodły się). Baskonia zachowała pewną autonomię polityczną i własne prawo, w tym tradycyjne prawa i przywileje - fueros ${ }^{3}$, nawet po wcieleniu jej do Królestwa Navarry, a potem Kastylii".

Po raz pierwszy Baskowie wyraźnie zaakcentowali swoją jedność hasłem Irrurac Bat ${ }^{5}$ i założeniem Towarzystwa Przyjaciół Kraju w 1765 r. w celu zacieśniania więzów pomiędzy prowincjami baskijskimi na podstawie wspólnoty językowej, kulturowej i etnicznej dla utrzymania baskijskiej niezależności. Wzajemna niechęć Basków i Kastylijczyków zarysowała się najostrzej, gdy madryckie władze, obawiając się konkurencji Basków w zarządzaniu nowymi koloniami, zepchnęły ich do roli obywateli drugiej kategorii, odmawiając im prawa do zajmowania wyższych stanowisk oraz używania euskary w urzędach i szkołach na terenie całego kraju. To zdarzenie zapoczątkowało walkę Basków o zachowanie tożsamości kulturowo-językowej.

Do rozwoju nastrojów narodowowyzwoleńczych przyczyniła się wówczas sytuacja ekonomiczna regionu, którą generowało szybko postępujące uprzemysłowienie. Dlatego też zalążki separatyzmu narodziły się w Vizcayi, gdzie napływ robotników z niebaskijskich części Hiszpanii powodował mieszanie się tubylców z imigrantami oraz pogorszenie się warunków społecznych tych pierwszych.

\section{-...}

2 Navarra nie wchodzi w skład dzisiejszej autonomii baskijskiej, lecz stanowi osobną wspólnotę autonomiczną. Fueros (hiszp.) - przywileje przyznawane wsiom, miastom i regionom przez władców hiszpańskich w czasach średniowiecza; określały one prawa i obowiązki. Fueros (przywileje), w ramach których Baskonia otrzymała pewną autonomię - własny system administracji lokalnej, pewną niezależność finansową i zwolnienie ze służby wojskowej poza swoją prowincją, w XIX wieku stały się przedmiotem rozgrywek politycznych i podstawą do roszczeń przywrócenia Baskonii autonomii.

4 Tło historyczne na podstawie M. Tuñon de Lara, J. Valdeón Baruque, A. Domínguez Ortiz, Historia Hiszpanii, Universitas, Kraków 1997.

5 Irrurac Bat (bask.) - oznacza siedem w jedności. Jest to nawiązanie do siedmiu baskijskich prowincji w myśl stworzenia jednej Baskonii, w skład której wchodziłyby cztery hiszpańskie i trzy francuskie prowincje zamieszkane przez Basków. Hasło to było później wykorzystywane przez ETA. 
W wyniku poparcia ${ }^{6}$, jakie Baskowie udzielili w XIX wieku karlistom7, Baskonia utraciła swoje przywileje i wielu jej mieszkańców wyemigrowało wówczas do Ameryki. Z kolei napływ do Baskonii imigrantów zarobkowych - zwanych meketos, głównie Asturyjczyków, Galicyjczyków i Kastylijczyków w drugiej połowie XIX wieku, spowodowat, iż wizerunek Kraju Basków ulegał zmianom. Nacjonalizm rdzennych mieszkańców regionu stawał się coraz bardziej wyraźny w miarę napływu meketos. Ludność Baskonii wzrastała więc liczebnie, ale groziło to utratą tożsamości narodowej.

Decyzje władz centralnych pozbawiające Basków, po ostatniej klęsce karlistów (w 1876 r.), wszelkich znamion odrębności prawnej stały się elementem konsolidującym społeczność baskijską i zarazem wyznaczającym programowy cel aktywności lokalnej. Zniesienie ostatnich przywilejów było połączone z polityką kadrową: wszystkie niemal stanowiska w administracji, szkolnictwie i hierarchii kościelnej obsadzono osobami o pochodzeniu niebaskijskim. Język lokalny wyłączony został z życia publicznego. Stworzyło to przesłanki splecenia się ruchu narodowościowego z rewindykacjami ekonomicznymi i społecznymi.

Nacjonalizm baskijski, jako ruch polityczny, narodził się za sprawą Sabino Arana y Goiri8 (1865-1903), który stworzył jego ideologię, nadał mu rozgłos i popularność, i tym samym rozpoczął nowy rozdział w historii tego narodu. Nie ulega jednak wątpliwości, że miał on poprzedników, którzy zbudowali fundamenty tej ideologii.

W politycznym życiu Sabino Arany historycy wyodrębniają trzy (bardzo odmienne) etapy: pierwszy - charakteryzujący się przekonaniami najbardziej radykalnymi i antyhiszpańskimi, opierającymi się jednocześnie na religii katolickiej; drugi - kiedy Arana porzucił idee ekstremistyczne i antykapitalistyczne i stał się przemysłowcem, w wyniku czego przestaje potępiać industrializację; trzeci - ostatni rok jego życia, który poświęca polityce prohiszpańskiej.

W lipcu 1895 r. powstała PNV, której założycielem był Sabino Arana. Chrześcijańskodemokratyczna partia, zgodnie z ideami Arany, opowiadała się początkowo za pełną niepodległością Kraju Basków. Jednak w czerwcu 1902 r. Arana zmienił swoją politykę na evolución españolista (ewolucja prohiszpańska) i opowiedział się za autonomią w ramach państwa hiszpańskiego. Arana, świadom, iż niemożliwe stało się zrealizowanie planów zdobycia niepodległości, zaczął nawoływać do porzucenia idei nacjonalistycznych i przekształcenia PNV w nową partię.

II Republika była okresem wielkiego splendoru dla PNV, która stała się główną siłą baskijskiego ruchu narodowego i pierwszą partią polityczną Baskonii. Gdy wojna domowa objęła całą Hiszpanię, Baskonia, w zamian za poparcie obozu rządowego (republikańskiego), 7 grudnia 1936 r. w Guernice proklamowała niepodległą Republikę Euskadii. Kortezy uchwality statut i na jego mocy w Bilbao powstał rząd baskijski. Statut Autonomiczny przyznał Krajowi Basków szereg przywilejów i praw lokalnych, między innymi prawo do posiadania własnego rządu i parlamentu, prowadzenia własnej polityki podatkowej, o czym mowa jest w art. 1 i 2 Statutu.

6 Silne poparcie, jakiego udzieliły karlistom Baskonia i Katalonia, wynikało z obawy, iż reformy pozbawia te regiony przywilejów i swobody zagwarantowanej w XVI wieku. Po stronie przegrywającej wojnę królowej Marii Krystyny stanęty Anglia i Francja. Karliści zostali pobici, ale pokój z Vergara w 1839 r. potwierdził wszystkie dawne przywileje prowincji. Po rozbrojeniu ostatnich oddziałów karlistów, rząd złamał to porozumienie.

7 Karliści - monarchiści hiszpańscy, którzy w latach 1833-1837 popierali prawo do korony Don Carlosa (a następnie jego potomków) przeciw liberalnej regentce Marii Krystynie.

8 Był on synem karlistowskiego oficera. Zaprojektował też flagę baskijską (zielony i biały krzyż na czerwonym tle), używaną do dziś przez władze Kraju Basków, a także przez ETA. 
Franco, świadom strategicznego znaczenia ziem Baskonii, właśnie na jej obszar przeniósł ciężar najważniejszych działań wojennych. Miał zamiar opanować baskijskie prowincje, w których znajdowała się większa część hiszpańskiego przemysłu ciężkiego. Zajęcie prowincji Vizcaya było dla frankistów zwycięstwem zarówno militarnym jak i politycznym, gdyż oznaczało kres potęgi ekonomicznej narodu i osłabienie pozycji nacjonalizmu baskijskiego, zagrażającego idei jedności narodu głoszonej przez Franco. Bilbao było największym miastem zdobytym do tego czasu przez nacjonalistów, a jego upadek stał się ciosem dla utworzonego 17 maja 1937 r. nowego rządu republikańskiego socjalisty Juana Negrina. Czterech ministrów tego gabinetu miało osobiste powiązania z Baskonią. 26 kwietnia 1937 r. lotnictwo hitlerowskie („Legion Condor") zbombardowało starą stolicę Baskonii, Guernikę.

Ostatecznie wojska frankistowskie opanowały jesienią 1937 r. cały teren autonomii baskijskiej, wszelkie prawa gwarantowane Statutem zostały Baskom odebrane. W wyniku walk i egzekucji zginęło 50 tys. Basków, a ponad 300 tys. wyemigrowało do Francji10.

Po zwycięstwie Franco prowadził bezwzględną politykę niszczenia baskijskiego nacjonalizmu. Sytuacja, w której znaleźli się Baskowie, spowodowała istotne zmiany w ich świadomości. W nieformalnym narodowym ruchu baskijskim, podczas wojny domowej, wyłonił się konserwatywny odłam karlistowski, którego przywódcą stał się Carlos de Burbon Parma. Karlistom wierni pozostali gtównie mieszkańcy Navarry i Alavy, choć większość Basków zaczęła odstępować od popierania karlistów na rzecz ruchu lewicowego, któremu sprzyjała zwłaszcza drobna burżuazja prowincji Guipúzcoa i Vizcaya, gdzie dominowała PNV.

Dla generała Franco postawa Basków, którzy w czasie rewolucji popierali republikę, stanowiła podstawę do zastosowania represji na niespotykaną dotychczas w dziejach tego narodu skalę. Zapowiedzią takich represji była ustawa o odpowiedzialności politycznej wydana 13 lutego 1937 r. Zgodnie z jej ustaleniami represjom mieli zostać poddani członkowie obozu republikańskiego i wszyscy ci, którzy przyczynili się do wywołania i podtrzymania "czerwonej działalności wywrotowej”. Jednocześnie zdelegalizowane zostały wszystkie partie republikańskie, związki zawodowe i stowarzyszenia oraz powiązane z nimi organizacje. Na podstawie tych decyzji Baskonia, a w szczególności Guipúzcoa i Vizcaya, stała się areną najkrwawszych represji. Aby rozbić ruch baskijski od wewnątrz, 24 kwietnia 1937 r. prowincje te uznano za zdradzieckie, co było równoznaczne z likwidacją ich autonomii i jakiejkolwiek niezależności. Jednocześnie podkreślone zostały zasługi Navarry i Alavy, które rzekomo udzieliły poparcia frankistom podczas wojny domowej, co umożliwiło tym regionom zachowanie własnej administracji. Stosując metodę divide et impera, Franco zamierzał rozwiązać problem nacjonalizmu w tym regionie ${ }^{11}$.

Do wyjątkowego natężenia terroru w Baskonii przyczyniła się również taktyka władzy polegająca na obsadzaniu urzędów państwowych weteranami armii nacjonalistycznej, co zapewniało precyzję we wdrażaniu dekretów generała Franco i gwarantowało efektywność metod faszystowskich. W tym czasie walka Basków o niezależność stała się prawie niemożliwa. Frankiści bardzo skutecznie zwalczali baskijską kulturę, gdyż bezwzględnie zakazali kultywowania jakichkolwiek regionalnych tradycji, w tym używania euskary, rozwiązano baskijskie stowarzyszenia kulturalne i naukowe, zabronione zostało wydawa-

9 Zob. H. Szymańska, Problem baskijski, [w:] W. Malendowski (red.), Spory i konflikty międzynarodowe. Aspekty prawne i polityczne, Atla 2, Wrocław 2000, s. 167

10 Szerzej zob. M. Kuczyński, Krwawiąca Europa. Konflikty zbrojne i punkty zapalne w latach 1990-2000. Tto historyczne i stan obecny, Dom Wydawniczy Bellona, Warszawa 2001, s. 343.

11 Zob. H. Szymańska, op. cit., s. 167-168. 
nie narodowych publikacji i przedstawianie folkloru. Do zaniku kulturowej kreatywności w tym czasie przyczyniła się także przymusowa emigracja twórców kultury.

Regres gospodarczy, który był skutkiem izolacji Hiszpanii, w dużym stopniu dotknął także Baskonię, co stopniowo rozbudzało nastroje rewolucyjne. Zjednoczenie antyfrankistowskich robotników w Guipúzcoa umożliwiło zorganizowanie strajku powszechnego w dniu 1 maja 1947 r., koordynowanego przez Komunistyczną Partię Baskonii. Objął on cały Kraj Basków i trwał do końca maja. Pomimo tych protestów i pierwszej reorganizacji rządu generała Franco, sytuacja w regionie nie uległa zmianie. Pewne ustępstwa rządu w dotychczasowej polityce blokowania dochodów zmotywowały protestujących do dalszych działań o radykalnym charakterze. Później, na początku lat sześćdziesiątych, w toku walk strajkowych zaczęła nabierać znaczenia nielegalna forma robotniczej organizacji, tzw. comisiones obreras (komisje robotnicze) ${ }^{12}$.

Napływ nowej siły roboczej (masowe emigracje chłopów z biednych terytoriów Hiszpanii - Galicji, Andaluzji i Kastylii) do Baskonii pogarszał sytuację społeczno-ekonomiczną przeciętnie zamożnych Basków. W rezultacie rdzenni Baskowie zmuszeni byli do przemieszczania się do innych regionów, również w celu znalezienia pracy. Zjawisko migracji interregionalnych było korzystne dla władz frankistowskich, gdyż stanowiło ważny punkt $w$ ich programie politycznym, propagującym ideę wchłaniania regionu przez centrum. Również w tym czasie zaczęła się kształtować elita ekonomiczna Hiszpanii, którą tworzyli w znacznej mierze najbogatsi Baskowie (łącząc się w ten sposób ze społeczeństwem globalnym) i Kastylijczycy.

Na emigracji działała nadal PNV, a jej tajny oddział, aktywny także na terenie Hiszpanii, cieszył się poparciem większości mieszkańców Baskonii. PNV czekała jednak biernie na nadejście lepszego układu politycznego, aby wtedy dążyć do zdobycia autonomii dla Kraju Basków. Ta właśnie bierna postawa stała się przyczyną powstania organizacji Euskadi Ta Askatasuna (Baskonia i Wolność) ${ }^{13}$, która skonsolidowała dotychczasowe podziemne siły walczące o niezależność Baskonii z aktywizującą się inteligencją ${ }^{14}$.

ETA działała w podziemiu przez sześć lat, aż wreszcie jej kierownictwo zdecydowało się na rozpoczęcie akcji zbrojnej przeciwko dyktaturze Franco. 31 lipca 1959 r. ETA zaczęła działać jawnie, określając się jako organizacja rewolucyjna i socjalistyczna, dążąca do narodowego wyzwolenia całej Baskonii, łącznie z baskijskimi okręgami we Francji. Od tej pory członkowie ETA rozpoczęli akty sabotażu, które przekształciły się później w międzynarodowe akcje terrorystyczne. Utworzenie ETA, która cieszyła się wówczas poparciem prawie całej Baskonii, stało się punktem zwrotnym w dotychczasowych ostrożnych reakcjach społeczeństwa baskijskiego na działania frankistów. Nowa organizacja bardzo szybko przejęła przywództwo ruchu baskijskiego z rąk dawnych działaczy PNV i stała się najsilniejszym ugrupowaniem w prowincjach Guipúzcoa i Vizcaya. W równie szybkim tempie zrodziły się jednak wewnętrzne rozbieżności ETA. Głównymi punktami spornymi stały się: stosunek do hiszpańskich partii opozycyjnych, program budowy przyszłego społeczeństwa oraz metody walki z frankizmem.

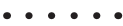

12 Były to komisje tworzone przez robotników w celu załatwienia jednej sprawy i później rozwiązywane.

13 Euskadi: baskijskie państwo obok innych państw świata; Askatasuna: wolni ludzie w ramach baskijskiego państwa. Dosłownie w języku baskijskim Euskadi Ta Askatasuna oznacza: Baskonia górą.

14 F. Rubiralta Casas, El nuevo nacionalismo radical. Los casos gallego, catalán y vasco (1959-1973), Tercera Prensa - Hirugarren Prentsa S.L., Donostia 1997. 
Fenomen ETA stanowi rezultat interakcji dwóch czynników - z jednej strony nacjonalizmu sabiniano, u podstaw którego leży pojmowanie Baskonii jako kraju okupowanego, i frankizmu, który sprawiał, iż ta okupacja stawała się rzeczywistością. Z tego powodu, by zrozumieć narodziny i późniejszy rozwój ETA, należy pamiętać o fundamentach ideologicznych i politycznych, na których opiera się nacjonalizm baskijski historyczny (czyli ten z okresu Sabino Arany), jak i o kontekście społecznym, politycznym i ekonomicznym okresu powojennego.

Według Gurutza Jáuregui istnieje pięć zasadniczych cech tworzących podstawy ideologiczne polityki nacjonalistycznej w Kraju Basków: czystość rasy, tradycjonalizm, zaściankowość, etnocentryzm, dośrodkowość/centryzm ${ }^{15}$. Nie wszystkie te elementy odegrały równie ważną rolę ani nie występowały z jednakową intensywnością. Gdyby spojrzeć przez pryzmat czasu, zaściankowość zniknęła całkowicie, a tradycjonalizm został znacznie ograniczony. Rasizm przerodził się w etnocentryzm.

W chwili obecnej nacjonalizm baskijski zdeterminowany jest głównie przez dwie cechy - etnocentryzm i dośrodkowość, rozumianą jako tendencja do zamknięcia się we własnym środowisku i budowanie wzorców nacjonalistycznych w oparciu o negację tego, co „inne” (dla przykładu: w Baskonii zawsze rządziła zasada ius sanguinis). Bezpośrednio z centryzmem wiąże się wyżej wymienione wyobrażenie o okupacji Kraju Basków przez Hiszpanię i dlatego nacjonalizm baskijski dążył zawsze do stworzenia takiej siły politycznej, której głównym celem byłaby walka o niepodległość Baskonii. Etnocentryzm, negując wszystko, co „obce”, tworzył społeczeństwo zamknięte, ograniczone czystością rasy, a także językiem - euskarą. Dla Sabino Arany czystość rasy stanowiła nie tylko fundament, ale także uosabiała to, co baskijskie. Euskara zaś, która zawsze była językiem mniejszości, nie mogła stanowić czynnika i elementu, który łączyłby społeczność baskijską, mogła jedynie spełniać funkcje symboliczne.

Od samego początku nacjonalizmem baskijskim targały sprzeczności: konieczność przyjęcia strategii umożliwiającej pogłębianie antagonizmu pomiędzy Baskonią i Hiszpanią oraz potrzeba posiadania bazy ideologicznej, która popierałaby nacjonalizm radykalny i bezkompromisowy (nawet fanatyczny). Z powodu tych właśnie różnic i swego rodzaju dwoistości powstały polityczne ugrupowania radykalne, które dały początek ETA.

Dla ETA jedynym możliwym rozwiązaniem problemu baskijskiego było zdobycie przez Baskonię niepodległości. Pomimo to, organizacja akceptowała idee integracji z federacją europejską.

\section{KONFRONTACJA NACJONALIZMU BASKIJSKIEGO Z DEMOKRACJA}

W 1976 r. władze w Madrycie zaproponowały utworzenie autonomicznego Kraju Basków. Dla ETA stanowiło to (kontrowersyjnie) problem, gdyż odbierało jej rację bytu. Można wysnuć wniosek, iż lata 1977-1979 dla społeczeństwa hiszpańskiego były okresem konsolidacji i umacniania systemu demokratycznego (wolne wybory, przyjęcie Konstytucji, a w przypadku Basków - Statutu Autonomii), to dla ETA stanowiły etap ustanawiania pod-

\footnotetext{
15 Szerzej zob. G. Jáuregui, ETA: Orígines y evolución ideológica y política, [w:] A. Elorza, J. Garmendia G. Jáuregui, F. Domínguez Iribarren, La historia de ETA, Ediciones Temas de Hoy, Madrid 2000, s. 172.
} 
staw sprzeciwu także wobec demokracji. ETA przyznała prymat aktywizmowi militarnemu, zaniedbując zupełnie aspekty polityczne i ideologiczne. W tym samym czasie kształtowały się instrumenty, za pomocą których ETA mogła kontrolować organizmy polityczne $\left(\mathrm{EH}^{16} \mathrm{i} \mathrm{HB}^{17}\right.$ ) i społeczne, które przyjęły jako priorytet popieranie zbrojnych grup w każdych okolicznościach. Najlepszym określeniem dla ETA począwszy od tamtego czasu jest vanguardia (straż przednia).

Niezgode pomiędzy ETA i PNV wywołało przyjęcie Statutu z Guerniki18 w 1979 r., co stanowiło rozszczepienie pomiędzy strategicznymi podejściami dwóch typów nacjonalizmu - politycznego i militarnego (antagonizm ten trwał ponad dwie dekady, a do zbliżenia doszło dopiero w 1998 r. podczas rozmów prowadzonych przez PNV, ETA i HB, co zaowocowało podpisaniem Paktu z Lizarra).

Lata pomiędzy rokiem 1977 a 1979 stanowiły także okres, w którym doszło do podziału w samym społeczeństwie baskijskim - na większość (w tym zwolennicy PNV), która optowała za zbiorowym projektem politycznym sformułowanym w Konstytucji i Statucie Autonomii, oraz mniejszość - ETA i jej zwolenników, którzy przekształcili się w siły antysystemowe, zafascynowani używaniem przemocy dla wywalczenia postawionych sobie celów.

W 1977 r., podczas gdy całe społeczeństwo hiszpańskie postępowało w stronę instytucjonalizacji systemu demokratycznego, który położyłby definitywny kres pozostałościom frankizmu, Kraj Basków funkcjonował w atmosferze ożywienia społecznego, mobilizacji politycznej i społecznej oraz rozruchów ulicznych, a wszelkie instytucje państwowe i administracji publicznej wydawały się zdyskredytowane i niewiarygodne. ETA w tym czasie stała się organizmem wszechobecnym, który zdawał się warunkować całe życie publiczne. Była też istotnym punktem odniesienia dla większości społeczeństwa baskijskiego. Generalnie, ocena działalności ETA była pozytywna, podczas gdy organizacja właśnie wtedy wkroczyła na droge muertes sin precedentes (ofiary śmiertelne bez precedensów). Musiało minąć prawie dziesięć lat, by mieszkańcy Baskonii porzucili swoją pozytywną percepcję bojowników ETA, którzy postrzegani byli jako patrioci, idealiści itp.

Dla Basków mógł to być okres pokojowego starania o samodzielność regionu. Po otrzymaniu od króla prawa do publicznego eksponowania symboli narodowościowych w 1976 r, Baskowie mieli nadzieję na nadanie kolejnych swobód po pierwszych w demokratycznym państwie wyborach parlamentarnych w czerwcu 1977 r. Były one szczególnie ważne dla społeczeństwa baskijskiego z uwagi na konieczność uchwalenia nowej ustawy zasadniczej, która między innymi rozstrzygała status mniejszości narodowych w ramach państwa hiszpańskiego. 31 grudnia rząd ogłosił decyzję o przywróceniu autonomii dla Kraju Basków ze stolicą w Vitorii, natomiast sprawę włączenia Navarry w skład autonomii baskijskiej postanowiono rozstrzygnąć poprzez przeprowadzenie referendum w tej prowincji. Powołano Radę Generalną jako tymczasowy rząd autonomiczny do czasu ostatecznego uregulowania tej kwestii w nowej konstytucji. Ustanowiono jednocześnie tzw. status przedautonomiczny, czemu jednak ETA ostro się sprzeciwiła, gdyż postanowienie to nie odzwierciedlało jej dążeń. 18 grudnia 1979 r. uchwalono w Kortezach Statut Autonomiczny Kraju Basków, który w drodze referendum został zaakceptowany przez społeczeństwo baskijskie. Na mocy tego dokumentu region baskijski stał się Wspólnotą Autonomiczną.

16 Euskal Herritarrok (bask.) - My, Obywatele Baskijscy.

17 Herri Batasuna (bask.) - Jeden Naród/Jedność Ludowa (różne tłumaczenia z języka baskijskiego).

18 Statut Autonomiczny Kraju Basków. 
Od połowy lat 90. XX wieku ETA zaczęła być traktowana (również przez samych Basków) jako wróg wszystkich obywateli, bez względu na pochodzenie etniczne. 17 lutego 1996 r. w skierowanej przeciwko tej organizacji manifestacji na ulicach Madrytu wzięło udział ponad milion osób z całego kraju, o co apelowały wszystkie ugrupowania polityczne, w tym po raz pierwszy również skrajna lewica. Także w Kraju Basków ludzie otwarcie protestowali przeciw ETA, pokonując strach przed zemstą organizacji i atakami ze strony bojowników Jarrai ${ }^{19}$. W odpowiedzi Herri Batasuna zorganizowała 24 lutego własną demonstrację, w której uczestniczyło ponad 30 tys. osób, co oznaczało, iż potępiana ETA ma nadal wielu sympatyków ${ }^{20}$, także za granicą (szczególnie skrajna lewica w Bretanii). W 1996 r. został opublikowany szczegółowy bilans konfliktu od pierwszych zamachów. ETA spotykała się z coraz szerszym potępieniem. Sami Baskowie byli przeciwni ETA do tego stopnia, iż zaczęli ujawniać policji miejsca pobytu terrorystów.

\section{NOWE KONCEPCJE ROZWIAZZANIA PROBLEMU BASKIJSKIEGO}

Mieszkańcy Baskonii nie wyrażają poparcia dla jakichkolwiek działań terrorystycznych ETA $^{21}$. Zdają sobie sprawę, że pełna niezależność jest niemożliwa do osiągnięcia, a w dobie Unii Europejskiej i tak szerokiej autonomii - nawet niekonieczna, natomiast walka narodowowyzwoleńcza ETA jest jedynie „przykrywką” dla fanatyzmu jej członków. 18 września 1999 r. w Bilbao odbył się zjazd baskijskich (francuskich i hiszpańskich - łącznie 1778 osób ${ }^{22}$ ) burmistrzów i radnych, na którym ogłoszono powstanie Zgromadzenia Gmin Baskijskich, obejmującego hiszpański i francuski Kraj Basków. Wydano wspólny komunikat, w którym opowiedziano się za dalszym rozszerzaniem autonomii baskijskiej w Hiszpanii i utworzeniem autonomicznego departamentu baskijskiego we Francji. Podczas gdy baskijskie społeczeństwo było tym pomysłom przychylne, rządy w Madrycie i Paryżu przyjęły tę wiadomość z jak najgorszymi podejrzeniami.

W roku 2000 PNV wzmocniła swoją pozycję i zwiększyło się dla niej poparcie społeczne, pomimo że od ponad dwóch lat pozostawała w sojuszu z EH, polityczne ramię ETA, sojusz wyborczy złożony z Herri Batasuna i kilku innych małych formacji skrajnej lewicy). PNV odniosła duży sukces podczas wyborów parlamentarnych, zwiększając liczbę reprezentantów - podobnie jak w wyborach do parlamentu regionalnego w roku 2001, podczas gdy poparcie dla EH spadło o połowę. José María Aznar nadal twierdził jednak, że "nie istnieje żadne ryzyko ani niebezpieczeństwo rozpadu Hiszpanii"23.

Strategia postępowania ETA, wspierana przez uznawanych do tej pory za umiarkowanych nacjonalistów z PNV24, wydaje się oczywista - zrealizowanie "wariantu irlandzkiego", czyli zmuszenie rządu do daleko posuniętych ustępstw. Postawa premiera była jednak jednoznaczna, gdyż również czas działa według niego na jego korzyść, ponieważ społeczne potępienie terrorystów i popierających ich polityków będzie w konsekwencji

19 Jarrai - bojówki młodzieżowe związane ideologicznie z ETA, działające na jej zlecenie (co było jednak utrzymywane w tajemnicy).

20 Co zresztą również potwierdzają kolejne wybory do Parlamentu. Pomimo spadku popularności, HB w pierwszej połowie lat dziewięćdziesiątych nadal miała swoich przedstawicieli w Kongresie Deputowanych.

21 Wynika to z analizy sondaży Sondeig d'Opinió przeprowadzonych przez Instytut Nauk Politycznych i Spotecznych w Barcelonie, <www.icps.es>

22 Ibidem.

23 Wywiad z José Maríą Nazarem, [w:] J. Pałasiński, Hiszpańska lekcja, "Wprost”, 26 marca 2000, nr 904.

24 Jako ciekawostke można podać, że PNV wspierała Ruch Autonomii "Śląska podczas wyborów samorządowych w 2003 r., służąc radami wynikającymi z własnych szerokich doświadczeń. 
oznaczało spadek poparcia dla PNV i wzrost zaufania do jego własnej Partii Ludowej25. Aznar nie widział możliwości odnowienia w Kortezach sojuszu z PNV, kiedy ta związata się z EH, więc wykorzystywał on każdą okazję, by atakować ją za sojusz z terrorystami (w domyśle - mordercami). ETA za to grozi wzmożeniem akcji terrorystycznych, jeśli rząd nie rozpocznie pertraktacji w sprawie niepodległości Kraju Basków, co przez Aznara w ogóle nie było brane pod uwagę. ETA zaczęła więc realizować swoje groźby, uderzając w najczulszy punkt Hiszpanii - turystykę, chcąc ją kompletnie sparaliżować

Poza najbardziej eksponowanym przez Basków aspektem historyczno-kulturowym jest jeszcze inny, o którym organizacja terrorystyczna, jaką stała się ETA, nigdy nie wspomina - Kraj Basków jest jednym z najlepiej rozwiniętych ekonomicznie regionów Hiszpanii, gdzie dochód narodowy na jednego mieszkańca jest najwyższy w kraju (poza okręgiem Madrytu). Baskonia ma również niemal wszystkie gałęzie przemysłu, a więc czuje się samowystarczalna i nie chce, by region był eksploatowany przez resztę kraju.

Warto również wspomnieć o dwóch sprawach. Pierwszą z nich jest związek skrajnie lewicowej ETA z Kościołem. Organizacja, która od początku swojej działalności zamordowała blisko 850 osób, założona została przez uczniów benedyktyńskiego seminarium duchownego w Lazkao i wiele swoich „sukcesów militarnych" zawdzięcza pomocy Kościoła, który zawsze wykazywał silne tendencje nacjonalistyczne (separatystyczne). ETA z pełną aprobatą lokalnej hierarchii eklezjastycznej przechowywała broń i materiały wybuchowe w kościołach, klasztorach i kaplicach, co stanowi paradoks zarówno ideologiczny jak i etyczno-moralny. Amerykański badacz Robert Clark twierdzi wręcz, że do roku 1968 73\% baskijskich księży było członkami ETA. Usprawiedliwiając przemoc ETA dążeniami uciskanego narodu do wolności, co stanowiło silny argument szczególnie w czasach dyktatury Franco, „Kościół baskijski pozostawia swój rozsądek etyczny, dopuszczając przemoc będącą wynikiem dążeń nacjonalistycznych" ${ }^{26}$. Wypowiedzi arcybiskupa San Sebastian, José Maríi Setiéna, przekonującego, że przemoc ETA jest uzasadniona, wielokrotnie powodowały konsternację, a nawet oburzenie - i to nie tylko w Madrycie, lecz także w Bilbao. Jego oświadczenie, że dialog z terrorystami powinien się rozpocząć zanim jeszcze przestali oni zabijać, spotkało się z reprymendą biskupa José Sancheza, rzecznika konferencji Episkopatu"27. Drugą interesującą kwestią jest propaganda ideologiczna głoszona przez ETA, iż naród baskijski nigdy nie został zdominowany przez inny, nie został podporządkowany, co stanowiło bazę dla późniejszej doktryny ETA usprawiedliwiającej walkę zbrojną w obronie suwerenności. Tymczasem naukowcy twierdzą, że odkryli w Kraju Basków co najmniej 250 osad rzymskich, kilkadziesiąt zbudowanych przez nich dróg i 50 mostów. Z odkopanych nekropolii merowińskich wynika, że i oni zadomowili się na tym obszarze. Nacjonaliści negują te odkrycia i dlatego zawód archeologa należy obecnie w Baskonii (szczególnie w Bilbao) do niebezpiecznych ${ }^{28}$.

Konflikt w Kraju Basków, pomimo iż zdaje się powoli wygasać, to ETA nadal jest aktywna i gotowa zabijać, atakując niewinnych ludzi, czemu bardzo trudno jest zapobiec. Poparcie dla separatystycznych idei jest w Baskonii bardzo niskie lok. 15\% w Hiszpanii i 10 we Francji). Pomimo że ETA liczy jedynie kilkudziesięciu bojowników, jej szeregi uzupełniane są na bieżąco z młodzieżowej organizacji bojówkarskiej Jarrai, a około 50 tys. wyborców Herri Batasuna stanowi bazę, z której wywodzi się kilka tysięcy aktywistów. Dopóki więc będą istnieli sympatycy idei separatystycznych, dopóty będzie istniała ETA, która nie zre-

25 Por. M. Onaindia, Guía para orientarse en el laberinto vasco, Ediciones Temas de Hoy, Madrid 2000.

26 Zob. G. de Cortázar, P. Fusi, Politica, nacionalidad e iglesia en el País Vasco, Alianza, San Sebastian 1988, s. 106.

27 J. Pałasiński, Gorący pokój, „Wprost”, 24 stycznia 1999, nr 843

28 Ibidem 
zygnuje z terroru i ofiar śmiertelnych. „Nawet poparcie niewielkiej grupy społecznej pozwala zdeterminowanej grupie terrorystycznej trwać praktycznie w nieskończoność" 29 . Konflikt etniczny w Kraju Basków udowodnit także, że ciężko jest walczyć z terroryzmem przy jednoczesnym, nieustannym zachowaniu wszystkich reguł państwa prawa (warto przypomnieć, iż to „szwadron śmierci” GAL ${ }^{30}$ spowodował przełom w walce z ETA).

Interesujący jest pogląd Basków na organizację państwa. Wzrasta poparcie dla idei niepodległościowych i federacyjnych, a spada dla pozostawienia obecnego kształtu, jednak społeczeństwo jest równo podzielone pomiędzy te trzy idee. Coraz więcej Basków utożsamia się bardziej z Baskonią niż z Hiszpanią, bądź z samą Baskonią, co wskazuje na wzrost świadomości narodowej i poparcia dla tendencji narodowościowych. Wzrasta również liczba osób identyfikujących się wyłącznie z Hiszpanią, co jest dowodem na to, iż w Baskonii jest coraz więcej ludności napływowej z innych regionów Hiszpanii, która nie identyfikuje się z regionem, w którym się osiedliła. Świadczy to również o braku asymilacji, bądź braku możliwości jej dokonania (czemu nie sprzyja polityka autonomii baskijskiej, utrudniając asymilację ludności napływowej) ${ }^{31}$.

Konieczne jest w tym miejscu przybliżenie Projektu Statutu Politycznego Kraju Basków, zwanego inaczej Planem lbarretxe z roku 2003. Na początku warto zilustrować fundamenty, na których opiera się ideologia zwolenników tego typu nacjonalizmu. Meritum stanowi podkreślanie i uwypuklanie (wręcz wyolbrzymianie) kwestii baskijskiej tożsamości narodowej, co powoduje dominację nacjonalistów nad resztą społeczeństwa, a co więcej - naród baskijski jest definiowany w ten sposób, że wyklucza znaczną jego część. Wewnątrz społeczności baskijskiej utworzyły się dwa antagonistyczne obozy: nacjonaliści i zwolennicy demokratyzacji społeczeństwa baskijskiego (którzy stanowią większość) ${ }^{32}$. Nacjonaliści baskijscy, proponując Plan Ibarretxe, kierują się jedynie własnym interesem oraz nietolerancją w stosunku do większości mieszkańców Baskonii. Widoczne jest to już w Preambule, która głosi, iż Kraj Basków posiada własną tożsamość, podobnie jak inne narody europejskie, składa się z siedmiu terytoriów, które podzielone są obecnie pomiędzy trzy ośrodki administracyjne i dwa państwa. Oznacza to, że nacjonaliści uznają za swoje terytoria, które, zgodnie z wolą mieszkańców i obowiązującym prawem, nie wchodzą w skład Baskoniij3. Takie sformułowanie i umiejscowienie narodu baskijskiego pośród innych narodów Europy implikuje jego suwerenność, co jest sprzeczne zarówno z Konstytucją Hiszpanii, jak i z obowiązującym Statutem Autonomicznym Kraju Basków. Ustęp 3 Preambuły zaś umożliwia mieszkańcom Navarry i trzech prowincji francuskich decydowanie o własnej przyszłości w kwestii przynależności terytorialnej. Takie podejście jest przyjęciem a priori, że mieszkańcy tych terytoriów stanowią część narodu baskijskiego (pomimo że oni wcale za takich się w większości nie uważają). Ponadto Statut Autonomiczny dawałby prawo połączenia się prowincji hiszpańskich z francuskimi w bliżej nieokreślony twór, co jest ingerencją w sprawy międzynarodowe, a więc niedopuszczalne ${ }^{34}$. Art. 6 wskazuje zaś na możliwość utworzenia specjalnych relacji pomiędzy Krajem

\section{$\cdots \cdot \cdot \cdot$}

29 M. Kuczyński, op. cit., s. 380.

30 Powołane do życia w 1983 r. przez służby bezpieczeństwa dla zwalczania terroryzmu (akcje wymierzone były głównie przeciwko terroryzmowi ETA)

31 Na podstawie sondażu Instytutu Nauk Politycznych i Społecznych w Barcelonie, <www.icps.es>

32 Nie oznacza to, iż to ugrupowanie nie pragnie zmian, ale w granicach, na które zezwala Konstytucja Hiszpanii i Statut Autonomiczny Kraju Basków.

33 Chodzi o Navarrę (której mieszkańcy w referendum powiedzieli, iż nie chcą być włączeni do Kraju Basków)، oraz o trzy prowincje należące do Francji. Oznacza to, że Statut miałby regulować także kwestie związane z terytoriami nienależącymi do wspólnoty, co jest sprzeczne z wszelkimi prawami.

34 Należy też pamiętać, iż mieszkańcy tych regionów już wyrazili swą wolę odnośnie do tej kwestii, więc Statut, wprowadzając powyższy zapis, ignorowałby ich wolę. 
Basków a Navarrą, a nawet stworzenie swoistej formy federacji, co jest sprzeczne z Konstytucją Hiszpanii (art. 145 ustęp 1). Jak słusznie zauważa A. Pérez Calvo ${ }^{35}$, rząd baskijski ma pragmatyczne podejście do Navarry, ciągle próbując ingerować w wewnętrzne sprawy tego regionu i wszelkimi sposobami starając się (bezskutecznie) włączyć Parlament Navarry do Generalnej Rady Baskijskiej (Consejo General Vasco). Wyraźnie widać, że nacjonaliści dążą do zmonopolizowania polityki Kraju Basków, chcąc wypowiadać się za cały naród. Zdania wśród konstytucjonalistów są podzielone. Jedni twierdzą, że Plan Ibarretxe jest sprzeczny z Konstytucją Hiszpanii, inni uważają, że zależy to wyłącznie od interpretacjij ${ }^{36}$. Generalnie, środowiska akademickie krytykują ten projekt, natomiast, jak wynika z przeprowadzonych przez "El País” sondaży i wywiadów, społeczeństwo baskijskie uważa, że zmiany zarówno Konstytucji, jak i Statutu Autonomicznego są potrzebne, ale powinni o nich decydować wszyscy mieszkańcy Kraju Basków, a nie politycy reprezentujący jedynie część społeczeństwa, która nie stanowi nawet większości.

Separatyzm baskijski jest problemem wielopłaszczyznowym, złożonym, w którym wiele aspektów nakłada się na siebie. „Nacjonalizm, w potocznym znaczeniu, jest postawą nieliczenia się z potrzebami i dążeniami innych narodów i narodowości. Najczęściej do gwałtownych konfliktów etnicznych skłania narody zbiorowa obawa o ich przyszłość, wyprowadzona z negatywnych doświadczeń przeszłości" ${ }^{\prime 37}$. Taka sytuacja miała miejsce w Baskonii. Nauczeni doświadczeniem (spychanie do roli obywateli drugiej kategorii w XVIII wieku, pozbawienie wszelkich przywilejów i autonomii w XIX wieku oraz tłumienie tożsamości narodowej i represje podczas wojny domowej, a nade wszystko w czasie dyktatury Franco), Baskowie postanowili walczyć o zachowanie swojej odrębności kulturowej i o szeroko pojmowaną autonomię, a nawet niezależność. Powstanie ETA było desperackim krokiem podjętym w celu walki przeciw dyktaturze generała Franco. Niestety, coraz bardziej drastyczne metody, które stosowała ETA, nadały jej charakter organizacji terrorystycznej. Po upadku reżimu frankistowskiego, kiedy Baskonia odzyskała dawno utraconą autonomię w ramach królestwa Hiszpanii (odrębny rząd, administracja, policja, system podatkowy i w pewnym zakresie prawo, natomiast język baskijski jest, obok kastylijskiego, oficjalnym językiem tego regionu ${ }^{38 ;}$; hiszpańska konstytucja umożliwia także zjednoczenie Baskonii z sąsiednią Navarrą zamieszkaną w połowie przez Basków), ETA nie zaprzestała swojej działalności i nadal dąży do uzyskania niezależności przez Baskonię, pomimo braku sympatii i poparcia, a nawet przy braku tolerancji ze strony narodu.

Słuszne wydają się słowa Hanny Szymańskiej:

„Problem baskijski jest paradoksem w realiach politycznych nie tylko Hiszpanii, ale i Europy. (...) Wraz z nacjonalizmem występują zalążki orientacji socjalistycznej (walka z wielką burżuazją niedbającą o czystość rasy). Z drugiej jednak strony widoczna jest gorliwa religijność i odcinanie się od przypisywanej fascynacji ideologią socjalistyczną oraz połączenie walki o przywileje socjalne z przesłankami narodowościowymi. Do tego należy dodać radykalizm ETA i poparcie uzyskane w początkowym okresie aktywności ze strony duchowieństwa. Kolejną sprawą, na którą warto zwrócić uwage jest lewicowy i jednocześnie nacjonalistyczny program ETA. I nade wszystko charakterystyczna jest determinacja Basków w pielęgnowaniu atrybutów narodowościowych, w tym historycznego języka, euskary - dumy Basków"39.

\section{-....}

35 A. Pérez Calvo, Estado, Nación y Soberanía (Problemas actuales en Europa), Departamento de Publicaciones del Senado, Madrid 2000, s. 20-21.

36 Takiego właśnie zdania jest Miguel Herrero de Miñón, jeden z ojców obowiązującej Konstytucji Hiszpanii. Uważa on, że interpretacja Planu Ibarretxe zależy od woli stron. Nie neguje on również możliwości wprowadzenia zmian do Konstytucji - tak wynika z jego wypowiedzi z wywiadów udzielanych El País.

37 R. Zięba, Instytucjonalizacja bezpieczeństwa europejskiego: koncepcje - struktury - funkcjonowanie, Wydawnictwo Naukowe, „Scholar” Warszawa 2001, s. 79-80.

38 W wielu szkołach jedynym, w jakim odbywa się nauka.

39 H. Szymańska, op. cit., s. 163. 
ETA, podobnie jak IRA, należy do najstarszych organizacji terrorystycznych i ma bardzo długą tradycję walki zbrojnej, która przekazywana jest z pokolenia na pokolenie ${ }^{40}$. Właśnie dlatego wielu młodych Basków „wpada w te kręgi niejako automatycznie i z reguły nie ma innego wyjścia, jak kontynuować działalność przodków"41. Powstaje więc niejako sytuacja paradoksalna. Gdy rząd Hiszpanii podejmuje próby stanowczego zwalczania terroryzmu, ujawniają się sympatycy ETA, pomimo braku poparcia w społeczeństwie baskijskim dla działań tej organizacji. W konsekwencji utrudnia to długotrwałe zaostrzanie metod stosowanych przez władze centralne i tym samym powoduje wzrost liczby bojowników ETA, zwiększając ich motywację do siłowego rozwiązywania problemów.

Z powodu braku poparcia społecznego dla idei niepodległości Baskonii, rząd nie jest w stanie pokojowo rozwiązać problemu (nawet, gdyby wprowadzono odpowiednią poprawkę do Konstytucji i stworzenie odrębnego państwa byłoby prawnie możliwe), gdyż ETA nie zmienia treści swoich żądań. Niezwykle trafne okazały się słowa Jesusa Eguigurena, sekretarza Baskijskiej Partii Socjalistycznej: „Rozwiązanie problemu baskijskiego nie jest kwestią dogadania się Basków z Hiszpanią, lecz Basków z Baskami"42. Trzeba też zgodzić się z poniższą opinią:

„ETA, która powstała, żeby zwalczać ucisk Basków, sama stała się aparatem ucisku. Chce przemocą narzucić większości ludności własne wyobrażenia. ETA mówi: do momentu, w którym więźniowie nie zostaną przeniesieni w jedno miejsce, a naród baskijski nie otrzyma niezależności państwowej, nie przestaniemy istnieć. Ale jest to zwykły pretekst, ponieważ ETA od dawna już stała się celem samym w sobie. Terroryści nie są w stanie dopasować się do zmienionej rzeczywistości politycznej, gdyż nie pojęli, że rzeczywistość przeszła obok nich"43.

Trudno przewidzieć, czy i kiedy, a najciekawsze - z jakich powodów ETA ostatecznie zakończy terrorystyczną walkę zbrojną. Idee niepodległościowe nie zostały zarzucone, co potwierdzają między innymi ataki terrorystyczne przeprowadzone przez ETA w rocznicę uchwalenia Konstytucji Hiszpanii. Tego typu tendencje wykazują też legalne komórki parlament baskijski uznat istnienie narodu baskijskiego, a rząd uznaje zdobycie suwerenności za jeden z ważnych elementów swojej polityki, jakkolwiek mało prawdopodobne może się to wydawać ${ }^{44}$. Oznacza to, iż kwestia suwerenności cały czas stanowi jeden z ważnych elementów w świadomości Basków, na co wpływ ma silnie zakorzenione poczucie tożsamości narodowej odrębnej od kastylijskiej.

Kwestia przemocy w społeczeństwie baskijskim, jak i ciągłe renegocjacje jego roli w Hiszpanii stanowią poważny problem, który może doprowadzić do trwałych podziałów nie tylko między społeczeństwem baskijskim i niebaskijskim, ale także wewnątrz tego społeczeństwa. Jakkolwiek różne jest podejście do kwestii statusu Kraju Basków i terroryzmu, któremu większość społeczeństwa baskijskiego jest przeciwna, to nie można jednak zaryzykować stwierdzania, że terroryzm jest jednoznacznie potępiany. Świadczyć o tym może fakt, iż ETA ma nadal grono zwolenników, wprawdzie niewielkie, ale umożliwiające organizacji nieprzerwaną egzystencję i gwarantujące jej rację bytu.

Z badań przeprowadzonych przez barceloński Instytut Nauk Politycznych i Społecznych wynika, że Basków cechuje silne poczucie tożsamości narodowej. Rdzenna ludność Baskonii w większym stopniu niż ludność „napływowa” wykształciła poczucie tożsamości

40 Szerzej zob.: E. Moxon-Browne, La Politica Etnica: Estudio Comparativo de lo Catolicos Norteirlandeses y los Vascos Españoles, „Revista de Estudios Políticos”, Enero/Marzo 1989, nr 63, s. 83-105.

41 V. Grotowicz, Terroryzm w Europie Zachodniej, Wydawnictwo Naukowe PWN, Warszawa 2000, s. 344.

42 J. Pałasiński, Gorący pokój, op. cit.

43 Wywiad z Lopezem Castillo, byłym członkiem kierownictwa ETA, cyt. za: V. Grotowicz, op. cit., s. 348.

44 Szerzej zob.: P. Muñoz Garcia, España en horas bajas. La guerra de los nacionalismos, Brand, Madrid 2000. 
odrębnej od kastylijskiej. Wynika to głównie z faktu, iż Baskowie identyfikują się jednak w większej części z Baskonią niż z Hiszpanią, czyli jako pierwszą podają narodowość baskijską, a dopiero potem hiszpańską, co wyraźnie świadczy o deklarowaniu tożsamości narodowej. Oznacza to, iż Baskowie uważają się za odrębny naród. Następstwem takiego stanu rzeczy jest chęć posiada ia szerszej autonomii, najlepiej w ramach hiszpańskiego państwa federalnego, albo uzyskanie niepodległości ${ }^{45}$.

BASQUE SEPARATISM

\section{Sum mary}

This article examines the origins of Basque nationalism, major reasons why the terrorist organization ETA was founded, and the evolution of ETA's activities. Alongside this discussion, a parallel history of moderate nationalism pursued by the Basque Nationalist Party is also examined. The article recognizes an historical approach, since Basque nationalism has evolved in a specific way, and the historical, political and systemic changes that influenced the Basque Country in a different way than in other regions of Spain.

In the literature, researchers show that Basque citizens are characterized by a strong sense of national identity. This is due firstly to the fact that many Basques identify themselves with the Basque Country rather than with Spain, which indicates a clear declaration of their national identity. This means that the Basques consider themselves a separate nation. The consequence of this is their desire to have a greater autonomy, preferably under the Spanish federal state, or to gain independence.

Keywords: nationalism, region, Basque national identity, nation, autonomy

45

Szerzej zob.: A. Antczak, Kształtowanie się tożsamości wspólnot autonomicznych w Hiszpanii, Wydawnictwo Akademii Obrony Narodowej, Warszawa 2008, s. 133. 